\title{
心蔵の洞房結節に分布する神経終末に 関する電子顕微鏡的研究
}

\author{
岡山大学医学部第一解剖学教室（指導：大塚長康教授） \\ 大塚長康・磯部保・根ケ山美和子・荻田成人
}

[昭和48年12月26日受稿〕

\begin{abstract}
粕言
De Robertis と Bennett ${ }^{11,2)}$, Palade $と$ Palay ら ${ }^{31}$ とって神経終末に出現する面径 200-500 $の$ empty な小胞の存在が報告されて以来,てれはシナ プス小胞としてシナプス前線維に特有な構造である ことか認められた．その後, この小胞之伝達物質の 関係が論議されるようになり,さらに研究が進めら れ，種々の性質を異にする小胞の存在が明らかにさ れてきた。その中でもモノアミン作働神経の終末に は電子密度の高い内容を含む小胞が見られるという

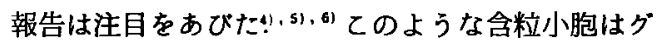
ルタルアルデヒド - 四酸化オスミウム固定のもの です観察できるが， $\mathrm{KMnO}$ 、を含んだ固定液を用いた 場合非常によく固定されることがわかった?!・，9

しかし，心㶓とくに刺激伝導系の神経終末を中心 に電子顕微鏡で観察し，その終末の形態を明らかに した研究は少くない! ${ }^{101111,12)}$ そでわれわれはイ邓 の刺激伝導系の洞房結節を用いて，KMnO，で固定 し，特にその神経終末に含まれる合粒小胞を中心に 検索した.
\end{abstract}

\section{材料と方法}

イヌ10例をラボナール麻醉下に脱血死し，ただち に心臓を開き，洞房結節領域を摘出，てれからさらに 小組織片を作り， $2 \% \mathrm{KMnO}_{4}$ 水溶液で 1 時間（4 $\left.{ }^{\circ} \mathrm{C}\right)$ 固定, エポン包埋し Porter-Blum I で薄切, JEM-7 型電子顕微鏡で観察した.

$$
\text { 所見 }
$$

イヌの洞房結節に分布する神経では,神経線維は数 本ずつが1 個の Schwann 細胞の細胞形質に取り囲 まれている，てれら神経線維は終末部になると多数 のシナプス小胞の集積か認められるようになる．終
末力特殊心筇細畇に接する側では，線維に随伴してき た Schwann 細胞が次如し，はだがになる。釉末部の 外表面はこれを取りまく基底膜でおおわれ，細隙をへ たててて筋細胞の外表面をおおう基底膜に相対している。 この細腺は通常1000 Å以上あり，ときには 2 枚の基 底膜の間に細い線維細胞の形質が介在しているとと がある. 終末部に面する筋形質には系粒体の集積, 多数のシナプス小胞大の空胞の存在が認められるこ とがあるほか, 筋細胞に pinocytosis の像がみられ ろ. 洞房結節に分布する神経終末内のシナプス小胞 には $\mathrm{KMnO}_{4}$ 固定ではグルタルアルデヒド固定とは 異なった像か観察できる，すなわち，終末部には無 含粒小胞のみを含んだ終末，小含粒小胞のみを含ん だ終末と，多数の小含粒小胞の中に散在性に大合粒 小胞を含む終末の 3 つの型のものが大部分を占め, それ以外の型のものはほとんど観察されない．てれ ら3つの型の終末部は, 1 つの Schwann 細胞任混 在して取り囲まれている場合が多い(図 1 )。

\section{考察}

神経終末に出現する含粒小胞は，その小胞の大き さからら, 小 (直径500 $\AA$ ), 中 (直径1000 $\AA$ ), 大(直

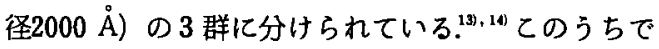
前 2 者が伝達物質としてのモノアミンと関係があり, 最後のものは神経分泌物や副腎髄質の顆粒に関係が あると考元られる。

てれら含粒小胞がモノアミンと関係が深いのでは ないかという推測は種々な実験的研究によって支持 された. しかし，合粒小胞とモノアミンの関係につ いては，まだ多くの解決しなければならない種々の 問題を含んでいる. ${ }^{15)}$

しかし，現時点では小含粒小盷はモノアそンと極 めて関係か深いと考えられている，大含粒小胞に対 してもモノアミンの貯蔵の場であるとも考えられて いるが，不明な点が多い:1611n さらに無含粒小胞はア 
セチルコリンと関係が深いと考えられている。 交感神経節後線維に含まれる小含粒小胞はグルタ ルアルデヒド・四酸化オスミウムではそのすへてを証 明するととができない. Richardson"p, Hökfelt,

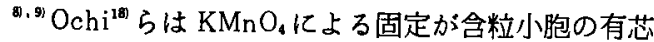
性顆粒を保存させるのに有効であり，その理論的寒 づけがなされてきた。

心臓に分布する神経線維内のシナプス小胞に含粒 小胞が出現するととは多数の研究者の報告がある. しかし, 刺激伝導系における神経終末に関する検索 は少くない.101,12, 191,201,211 大塚 ${ }^{199} や$ Hayashi et al.01は イヌの洞房結節をグルタルアルデヒドで固定した後， その特殊心筋線維に終わる神程終末を観察しだ。そ の結果, その内部に含有されるシナプス小胞の形の 上から終末部を 5 型に分類した.すなおち，I）無 含粒小胞（百径約 $500 \AA$ )のみからなるもの，II）無 含粒小胞と大含粒小胞（直径約 $1000 \AA$ ）力混在する もの，III）無含粒小胞と小含粒小胞（直径約 $500 \AA$ ） が混在するもの, IV) 無含粒, 小含粒さらに大含粒 小胞か混在するもの，V）大含粒小胞のみからなる ものの 5 種類である.

一方，本研究において明らかになったように，

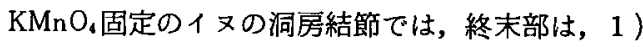
無含粒小胞のみを含んだ終末，2）小含粒小胞のみ を含んだ終末と，3）多数の小含粒小胞の中に散在 性に大含粒小胞を含む終末の 3 つの型のもののみが 観察された。

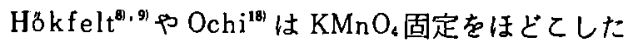
場合,てれは生体アミンと反応して, 還元され $\mathrm{MnO}_{2}$ となって電子密度の高い顆粒となって小胞の中に沈 殿するものと考えている。

したがって，われわれの研究結果では $\mathrm{KMnO}_{\text {固 }}$ 定では上記の上うに3つの型のものが大部分を占め， それ以外のものははとんど観察されなかった. この
ととは Hayashi et al.が行なった研觉のようにグル タルアルデヒド固定では特に小含粒小胞の顆粒の成 分がー部溶出されるために無含粒小胞と小含粒小胞 とが混在した型のものが観察できるが， $\mathrm{KMnO}_{1}$ 固定 ではみとめられなくなるものと考えられる．したが って，本研究において出現した終末構造で，1）に 属するものはコリン作㗢神経の終末であり，2）と 3 ）に属するものは,モノアミン作働神経の終末で あろうと推察することができる.

終末部では数個の種々の型が混在した神経終末が 1 個の Schwann 細胞に取り囲まれながら 1 個の筋 細胞に終わる形態を取るととが多い，したがって， 1 個の筋細胞はコリン作働とモノア そン作働神経の 二重支配の下に調節を受けているものと思われる. さらに心臓内にみられる神経終末の中に多数のミ トコンドリアを含んだものが観察され，てれを心蔵 の知覚神経の終末であろうと考えられている ${ }^{22}$ が, 本研究ではこのような終末を認めることができなか った.

\section{結語}

イヌの心臓刺激伝導系の洞房結節を $\mathrm{KMnO}$ 、で固 定し，そしに分布する神経終末を笔子顕微鏡で観察 した.

その結果, 洞房結節の神経終末を, その部に含ま れるシナプス小胞の形の上から 3 型の䅂末部に分類 することができた．すなわち，1）無含粒小胞のみ からなるもの，2）小含粒小胞のみからなるもの， 3) 小含粒小胞と大含粒小胞加なるちのの3 種類 である.この3 種類の型をもった終末部を㭘討した 結果，1）に属するものはコリン作働神経，2）お よび3）に属するむのはモノアミン作㗢神経の終末 であることがわかった。

\section{文献}

1) DE ROBERTIS, E. D. P. and BENNETT, H.S. ; Submicroscopic vesicular component in the synapse. Fed. proc., 13, 35, 1954.

2) DE ROBERTIS, E. D. P. and BENNETT, H. S. ; Some features of the submicroscopic morphology of synapses in frog and earthworm. J. Biophys. Biochem. Cytol., 1, 47-58, 1955.

3) PALADE, G. E. and PALAY, S. L. ; Electron microscope observation of interneuronal and neuromuscular synapses. Anat. Rec., 18, 335, 1954. 
4) VON EULER and HILLARP, N. A.; Evidence for the presence of noradrenaline in submicroscopic structures of adrenergic axons. Nature, 177, 44-45, 1956.

5 ) ELFVIN, L. G.; The ultrastructure of unmyelinated fibers in the splenic nerve of the cat. J. Ultrastr. Res., 1, 428-454, 1958.

$6)$ DE ROBERTIS, E. and PELLEGRINO DE IRALDI, A.; Pluvivesicular secretory process and nerve endings in the pineal gland. J. Biophys. Biochem. Cytol., 10, 361-372, 1961.

7 ) RICHARDSON, K. C.; Electron microscopic identification of autonomic nerve endings. Nature, 210, 756, 1966.

8 ) HÖKFELT, T; On the ultrastructural localization of noradrenaline in the central nervous system of the rat. Z. Zellforsch., 79, 110-117, 1967.

9) HÖKFELT, T; In vitro studies on central and peripheral monoamine neurons at the ultrastructural level. Z. Zellforsch., 91, $1-74,1968$

10) HAYASHI, S., OGA, K. and OTSUKA, N.; The fine structure of nerve endings in the sinus node of the canine heart. J. Electron Micr., 19, 176-181, 1970.

11) NILSSON, E. and SPORRONG, B; Electron microscopic investigation of adrenergic and nonadrenergic axon in the rabbit SA-node. Z. Zellforsch., 111, 404-412, 1970.

12) THAEMERT, J.C; Atrioventricular node innervation in ultrastructural three dimension. Am. J. Anat., 128, 239-264, 1970.

13) GRILLO, M. and PALAY, S.L; Granule-containing vesicles in the autonomic nervous system. In: Fif th Internat. Congr. for Electron Micr., Philadelphia, Edit. by S. S. Breese Jr., vol. 2, U-1, Academic Press, New York, 1962.

14) PELLEGRINO DE IRALDI. A. and DE ROBERTIS, E.; Ultrastructure and function of catecholamine containing systems. In: Proc. 2 nd Internat. Congr. Series, No.83, 355-363, 1964.

15）传野豊；モノアミン作㗢ニューロンの研究. 最新医学, 25, 2031-2048, 1970.

16) KAPELLER, K. and MAYOR, D.; The accumulation of noradrenaline in constricted sympathetic nerves as studied by fluorescence and electron microscopy. Proc. R. Soc. Ser., B. 167, $282-292,1959$.

17) SANO, Y., YOSHIKAWA, H. and OCHI, J; Intraneuroplasmic transport of catecholamines as studied by fluorescence and electron microscopy. Arch. histol. jap., 32, 329-345, 1970.

18) OCHI, J.; A study of potassium permanganate fixation for electron microscopic detection of small granular vesicles in the sympathetic nervous system. Acta Histochem. Cytochem., 2 , $13-18,1969$.

19）大塚長康；心瀻に分布するモノア ミン作働線維. 日本医師会雑誌，64，1044-1049, 1970.

20) HAYASHI, S; Electron microscopy of the heart conduction system of the dog. Arch. histol. jap., 33, 67-86, 1971.

21) CHENG, Y; The ultrastructure of the rat sino-atrial node. Acta Anat. Nippon, 46, 339-358, 1971.

22) CHIBA, T. and YAMAUCHI, A.; On the fine structure of the nerve terminal in the human myocardium. Z. Zellforsch., 108, 324-338, 1970. 


\title{
Electron Microscopic Study on Nerve Endings in the
}

Sinus Node of the Heart.

\section{Nagayasu OTSUKA, Tamotsu ISOBE, Miwako NEGAYAMA and Shigeto KANDA}

\author{
Department of Anatomy, Okayama University Medical School \\ (Director: Prof. Nagayasu OTSUKA)
}

The sinus node of the canine heart contains numerous autonomic nerve fibers. All of these are unmyelinated fibers associated with the cytoplasm of Schwann cell. The axon terminals, however, are devoid of such processes and are separated from the myocardial cells by an unusually wide space. In these naked nerve ending, 3 types of vesicles are observed: small granular vesicles, large granular vesicles, and agranular vesicles. The distribution of the vesicles by $\mathrm{KMnO}_{4}$-fixation has enabled us to classify autonomic nerve endings into 3 categories. 


\section{大塚 他 3 名 論 文附 図}

図 1、洞房結節にみられる小含粒小胞を含んだ神経終末，イヌ， $\mathrm{KMnO}_{4}$ 固定 ; $\times 40,000$

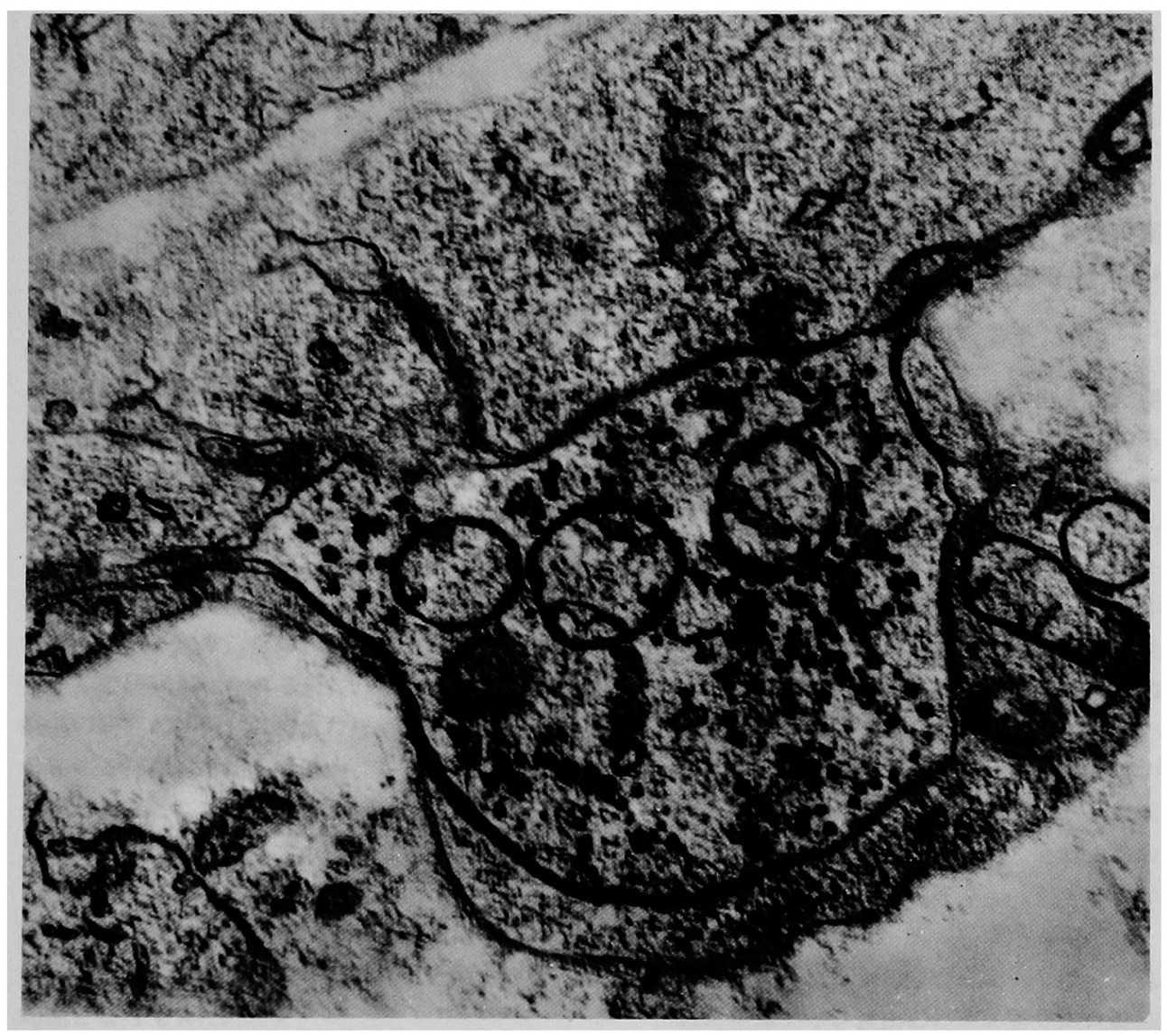

